\title{
B.RP:AC
}

Instructions for authors, subscriptions and further details:

http://brac.hipatiapress.com

\section{La Cascarilla Cerámica como Material Escultórico}

Carmen Marcos Martínez¹.

1) Departamento de Escultura, Facultad de Bellas Artes de San Carlos. Universidad Politécnica de Valencia, España.

Date of publication: June, 3rd 2013

To cite this review: Marcos, C. (2013). La Cascarilla Cerámica como Material Escultórico (Review of the doctoral thesis). Barcelona, Research, Art, Creation, 1 (1), 127-129. doi: 10.4471/brac.2013.05.

To link this article: http://dx.doi.org/10.4471/brac.2013.05

\section{PLEASE SCROLL DOWN FOR ARTICLE}

The terms and conditions of use are related to the Open Journal System and to Creative Commons Non-Commercial and Non-Derivative License. 
BRAC - Barcelona Research Art Creation. Vol. 1 No. 1, June 2013 pp.

$127-129$

\section{Reviews (I)}

Petrillo, L. (2013). La cascarilla cerámica como material escultórico. (Tesis doctoral no publicada). Universidad de Barcelona, Barcelona, España.

La tesis que citamos fue defendida en la Facultad de Bellas Artes de Barcelona el 22 de enero de 2013, y tuvimos el honor de formar parte del tribunal.

Quisiéramos dibujar el contexto histórico e investigador en el que se puede inscribir esta investigación. En 1996 Mr. David Reid impartió un taller que organizamos en el Departamento de Escultura de la Facultad de Bellas Artes de Valencia, titulado "Fire Technologies in the Making of Sculpture", en el que se realizaron moldes experimentales aglutinados con materias orgánicas, con refractarios alternativos, con moldes no refractarios. Una de las reflexiones finales del curso de Mr. David Reid fue comentar que teníamos "entre manos" un material exquisito, la cáscara cerámica que usábamos como material de molde perdido, y por tanto lo rompíamos, lo tirábamos, pero que al fin y al cabo era una cerámica, una cerámica de grandes cualidades. Desde entonces no hemos parado hasta encontrar un sentido y expresión escultórica a la propuesta del maestro. Dos Congresos de Investigadores en Fundición Artística después (2006 y 2009, celebrados ambos en la Facultad de Bellas Artes de Valencia), la tesis de D. Lucido Petrillo recoge y presenta la cáscara cerámica como material escultórico, desarrollo completo de su participación precisamente en el II Congreso con un artículo titulado "Experiencias y estudio de resistencias de la

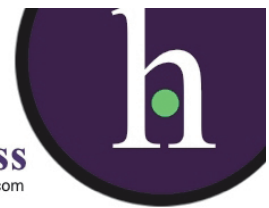


cascarilla cerámica para su uso como material escultórico". Este congreso se completaba con una exposición de esculturas entre las cuales tanto la de D. Lucido como la de quien suscribe estas líneas eran propuestas escultóricas en cáscara cerámica.

Toda la tesis tiene un marcado carácter empírico-experimental. Está estructurada en cinco capítulos de contenidos, de los cuales los tres primeros se centran en someter al material que ya conocemos, a la cáscara cerámica, a una revisión de reconocimiento, que incluye análisis de componentes, pruebas de resistencia teniendo el sílice coloidal PW50 (nombre comercial del sílice coloidal suministrado por Comercial Química Massó) como aglutinante central de la investigación, y procedimientos escultóricos tradicionales. En esta primera parte de la tesis consideramos una aportación especial la elección del uso del PW50, dado que hasta fecha muy reciente, el sílice coloidal citado y empleado habitualmente en las fundiciones artísticas era el Hispasil 17.31 .

De esta primera parte de la tesis destacamos las imágenes de microscopía realizadas con el SEM sobre secciones de diferentes muestras de cáscara cerámica por ser en si una aportación científica de relevante interés que el seno de la Universidad puede viabilizar para incrementar y mejorar el campo de conocimiento de la Escultura.

Resultan de gran interés los capítulos IV y $\mathrm{V}$, en los que la tesis muestra sus aspectos más puramente creativos. Cierto que los capítulos previos preparan y abonan el terreno para poder desarrollar con fluidez y "tranquilidad" técnica los dos siguientes, pero pensamos que la amplitud y complejidad de la primera parte de la tesis ha restado tiempo de explorar las verdaderas posibilidades creativas de la investigación en si. El capítulo IV, que aborda los tratamientos superficiales de la cáscara cerámica resulta a todas luces innovador, desde la mezcla de la barbotina de primera capa con otros materiales, como las limaduras de hierro y/o bronce, hasta el uso de esmaltes y acabados cerámicos industriales, comerciales. El capítulo V, titulado "Experiencias de la aplicación de la cáscara cerámica como material escultórico", es el que da sentido a todo lo investigado de forma más empírica en los capítulos anteriores. Se trata de crear esculturas con los diversos procedimientos ensayados y con las premisas técnicas que marcan una calidad de trabajo buena. Se presentan trabajos de creación propia, pero también de 
compañeros e incluso de sus dos directores de tesis, con lo cual se ha alcanzado una mayor riqueza y profundidad, tanto formal como estilística. Muchas de estas piezas presentadas han participado en exposiciones colectivas, con lo que consideramos se ha cerrado el ciclo de comunicación que es inherente al acto creativo.

Como valoración final nos gustaría expresar nuestra comunión con el planteamiento de esta tesis doctoral. Desde nuestros inicios como profesora asociada en la Universidad Politécnica de Valencia, en los que nuestra actividad profesional compaginaba la creación escultórica en el taller personal con las clases en la universidad, hemos entendido que docencia, creación e investigación van unidas. Creemos en una investigación en la que la técnica apoye y estimule lo creativo, un hermanamiento entre investigación técnica y creación escultórica.

Carmen Marcos, Universidad Politécnica de Valencia carmemarcos@gmail.com 